\title{
Gea
}

JURNAL PENDIDIKAN GEOGRAFI

\section{PENGEMBANGAN BUKU TEKS DIGITAL INTERAKTIF UNTUK PEMAHAMAN KONSEP GEOGRAFI}

\author{
Nani Suryani ${ }^{1}$, Mamat Ruhimat ${ }^{2}$, Epon Ningrum ${ }^{3}$ \\ Prodi Pendidikan Geografi, SPs, UPI, \\ email : nanisuryani898@gmail.com
}

\begin{abstract}
The research aims to develop Interactive Digital Textbooks for Geography concept understanding on the topic of the Environment by adopting RED (Research and Development) method. The design of Interactive Digital Textbooks was validated by three validators, namely two validators for content and one validator for the media. To find the effectiveness of the Interactive Digital Textbooks, an experiment with randomized control group pretest-posttest design was employed. Meanwhile, the research subjects for the product testing were the eleventh grade students of UPI (Indonesia University of Education) Laboratory Senior High School. Based on empirical test, it is found that there was a difference in experimental class students' scores before and after treatment with Interactive Digital Textbooks I and II. The difference was evidenced in the increased average score after the treatment. It is also found that there was a difference in control class students' test results before and after treatment with conventional Textbooks I and II. The difference is showed by increased average score after treatment. Furthermore, there was a difference in concept understanding between experimental class students who used Interactive Digital Textbooks I and II and those of the control class treated with Textbooks I and II. The difference suggests that there was improvement in the concept understanding of both experimental and control class students. Hence, the developed Interactive Digital Textbooks had influence on students' concept understanding in Geography subject.

Keywords: interactive digital textbooks, concept understanding.
\end{abstract}

\section{PENDAHULUAN}

Pendidikan merupakan suatu usaha sadar, terencana, serta disengaja untuk mengembangkan dan membina sumber daya manusia. Pendidikan dilaksanakan dalam bentuk belajar dan proses pembelajaran, dengan tujuan para pembelajar dapat mengembangkan potensi yang ada dalam dirinya.

Pendidikan merupakan suatu hal yang sangat penting bagi keberlangsungan hidup manusia. Apabila seseorang mempunyai pendidikan yang baik, maka secara otomatis akan mempunyai wawasan ilmu pengetahuan yang baik. Hal ini menunjukan betapa sangat pentingnya pendidikan bagi kehidupan manusia dan memiliki berbagai fungsi untuk menunjang masa depan seseorang.

Dalam dunia pendidikan, dikenal adanya kegiatan pembelajaran. Soetomo
(1993, hlm. 68), mengemukakan bahwa “pembelajaran adalah proses pengelolaan lingkungan seseorang yang dengan sengaja dilakukan sehingga memungkinkan dia belajar untuk melakukan atau mempertunjukkan tingkah laku tertentu pula".

Magasing (2012, hlm. 24), bahwa pembelajaran memiliki komponen-komponen yang terdiri dari: 1) sumber belajar, 2) media pembelajaran, 3) fasilitas belajar, 4) tujuan pembelajaran, 5) metode pembelajaran, 6) guru, 7) siswa. Berdasarkan hal tersebut, dapat diketahui bahwa sumber pembelajaran merupakan salah satu bagian dari komponen pembelajaran yang tidak boleh dihilangkan.

Rohani (1997, hlm. 102), menyatakan bahwa sumber belajar dapat bermanfaat dalam hal-hal berikut. 1) Memberi pengalaman belajar secara langsung dan konkret kepada siswa. 2) Dapat menyajikan sesuatu 
yang tidak mungkin diadakan, dikunjungi, atau dilihat secara langsung dan konkrit. 3) Dapat menambah dan memperluas cakrawala sajian yang ada di dalam kelas. 4) Dapat memberikan informasi yang akurat dan terbaru. 5) Dapat membantu memecahkan masalah pendidikan (instruksional) baik dalam lingkup mikro maupun makro. 6) Dapat memberikan motivasi positif, apabila diatur dan direncanakan pemanfaatannya secara tepat. 7) Dapat merangsang untuk berpikir, bersikap dan berkembang lebih lanjut.

Buku teks merupakan salah satu sumber belajar dan bahan ajar yang banyak digunakan dalam pembelajaran, termasuk dalam pembelajaran Geografi di SMA Laboratorium Percontohan UPI Bandung. Buku teks memang merupakan bahan ajar sekaligus sumber belajar bagi siswa yang konvensional.

Namun, buku teks memiliki kelemahan-kelemahan yang dapat mengganggu tercapainya tujuan pembelajaran, antara lain sebagai berikut. 1) Dapat memakan waktu beberapa hari sampai berbulanbulan dalam mencetak medianya. 2) Mencetak gambar atau foto berwarna biasanya memerlukan biaya yang mahal. 3) Sukar menampilkan gerak di halaman media cetak. 4) Pelajaran yang terlalu banyak disajikan, dengan buku teks cenderung untuk mematikan minat dan menyebabkan kebosanan. 5) Tanpa perawatan yang baik, media cetak akan cepat rusak, hilang, atau musnah. 6) Berat dibawa di dalam tas. 7) Dalam materi tertentu, penggunaan buku teks harus dibantu alat peraga.

Seiring perkembangan Teknologi Informasi (TI) yang semakin pesat, sumber belajar juga harus mampu menampilkan simulasi-simulasi interaktif dengan memadukan video, animasi, audio, dan gambar. Perpaduan tersebut dapat membantu peserta didik untuk memvisualisasikan suatu materi pembeljaran yang bersifat abstrak sehingga peserta didik dapat memahami konsep dalam materi tersebut.
Salah satu alternatif sumber pembelajaran yang dapat digunakan sebagai solusi permasalahan tersebut adalah Buku Teks Digital Interaktif. Menurut Andina (2011, hlm. 123), buku digital merupakan publickasi berupa teks dan gambar dalam bentuk digital yang diproduksi, diterbitkan, dan dapat dibaca melalui komputer atau alat digital lainnya. Sedangkan interaktif itu sendiri didefinisikan sebagai kegiatan saling melakukan interaksi (berlangsung dua arah) antara buku digital dengan pengguna (user).

Buku Teks Digital Interaktif yang akan dimanfaatkan sebagai sumber belajar dalam penelitian ini tidak hanya berupa serangkaian teks-teks materi pelajaran saja, akan tetapi dapat juga diberi tambahan berupa gambar interaktif, glosari interaktif, video serta animasi. Dengan kata lain, Buku Teks Digital Interaktif dilengkapi pula dengan unsur multimedia lainnya. Adapun Buku Teks Digital Interaktif yang dirancang untuk sumber belajar akan dikemas dalam bentuk flip book.

Adapun beberapa keunggulan Buku Digital Interaktif, seperti yang dikemukakan Perdana (2013, hlm. 52), yaitu: 1) pembelajaran dengan Buku Digital Interaktif menarik, 2) tujuan pembelajaran dapat dirumuskan dengan jelas di dalam Buku Digital Interaktif, 3) penyajian materi tersusun secara sistematis dengan materi yang lengkap, 4) petunjuk penggunaan jelas, 5) animasi dan video yang disajikan dapat membantu pemahaman siswa, 6) soal latihan dikemas dengan desain menarik sehingga membuat siswa tertarik untuk belajar, 7) Buku Digital Interaktif membantu dalam mempersiapkan media untuk mengajar bagi guru serta media belajar mandiri bagi siswa.

Salah satu permasalahan dalam pembelajaran geografi adalah kurangnya penggunaan sumber belajar berkualitas yang menunjang pencapaian tujuan pembelajaran. Berdasarkan permasalahan tersebut, perlu kiranya seorang pendidik untuk mencoba mengatasi hal tersebut 
dengan mengembangkan sumber belajar yang lebih bersifat interaktif, serta meningkatkan konsentrasi peserta didik terhadap materi yang disampaikan oleh guru sehingga peserta didik mampu memahami konsep materi pembelajaran dengan optimal, yaitu dengan pengembangan Buku Teks Digital Interaktif.

Berdasarkan uraian yang telah dikemukakan tersebut, maka diadakan penelitian mengenai "Pengembangan Buku Teks Digital Interaktif untuk Pemahaman Konsep Geografi".

Rumusan masalah penelitian ini adalah: 1) Bagaimanakah tingkat pemahaman konsep peserta didik kelas XI Sosial Humaniora di SMA Laboratorium Percontohan UPI Bandung? 2) Bagaimanakah pengembangan Buku Teks Digital Interaktif yang dapat meningkatkan pemahaman konsep peserta didik? 3) Bagaimanakah efektifitas uji coba pemanfaatan Buku Teks Digital Interaktif dalam meningkatkan pemahaman konsep peserta didik?

Secara umum tujuan yang ingin dicapai dalam penelitian adalah mengembangkan Buku Teks Digital Interaktif untuk pemahaman konsep peserta didik. Secara khusus tujuan penelitian: 1) Mengidentifikasi pemahaman konsep peserta didik kelas XI Sosial Humaniora di SMA Laboratorium Percontohan UPI Bandung. 2) Mengembangkan Buku Teks Digital Interaktif yang dapat meningkatkan pemahaman konsep peserta didik. 3) Mengidentifikasi efektifitas uji coba pemanfaatan Buku Teks Digital Interaktif dalam meningkatkan pemahaman konsep peserta didik.

\section{METODE PENELITIAN}

Metode penelitian menggunakan Research and Development. Metode $R \& D$ ini bertujuan untuk menghasilkan produk, di mana produk yang dihasilkan adalah Buku Teks Digital Interaktif untuk pemahaman konsep peserta didik.

Dalam penelitian ini, penulis melakukan lima tahapan R\&D yang diadaptasi dari Sugiyono (2014), yaitu: (1) Studi
Pendahuluan (Pemahaman Konsep dan Penggunaan Sumber Belajar), (2) Studi Pustaka, (3) Pembuatan Draft dan Desain Buku Teks Digital Interaktif, (4) Uji Validasi dan Revisi, (5) Uji Empiris Buku Teks Digital Interaktif, sehingga mendapatkan (6) Hasil.

Validasi draft Buku Teks Digital Interaktif dilakukan oleh Prof. Dr. Wanjat Kastolani, M.Pd, dan Dr. Lili Somantri, S.Pd, M.Si sebagai ahli materi, serta Dr. Ahmad Yani, M.Si sebagai ahli media. Adapun subjek penelitian untuk uji coba produk adalah peserta didik SMA Laboratorium Percontohan UPI Bandung kelas XI Sosial Humaniora 1.

Uji Empiris Buku Teks Digital Interaktif dilakukan melalui eksperimen dengan desain randomized control group pretest-posttest design. Instrumen penelitian yang dibuat meliputi lembar observasi, dan soal tes pemahaman, serta Lembar Kerja Siswa (LKS).

\section{HASIL DAN PEMBAHASAN}

Hasil penelitian menjelaskan tentang bagaimana pemahaman konsep peserta didik kelas XI Sosial Humaniora, langkahlangkah pengembangan Buku Teks Digital Interaktif untuk pemahaman konsep geografi, dan efektifitas Buku Teks Digital Interaktif terhadap pemahaman konsep peserta didik.

Secara keseluruhan, hasil tes pemahaman konsep kelas XI Sosial Humanira dapat dilihat pada Tabel 1.

Tabel 1. Hasil Pemahaman Konsep Peserta Didik Kelas XI SOSHUM

\begin{tabular}{cccc}
\hline & \multicolumn{3}{c}{ Frekuensi } \\
\cline { 2 - 4 } Interval & $\mathrm{XI}$ & $\mathrm{XI}$ & $\mathrm{XI}$ \\
& SOSHUM & SOSHUM & SOSHUM \\
& 1 & 2 & 3 \\
\hline $4-60$ & 16 & 16 & 18 \\
\hline $61-80$ & 11 & 18 & 13 \\
\hline $81-100$ & 3 & 2 & 4 \\
\hline Jumlah & 30 & 36 & 35 \\
\hline
\end{tabular}

Berdasarkan tabel 1, dari jumlah peserta didik secara keseluruhan yaitu 101 orang, hanya 9 peserta didik yang menda- 
pat nilai pada interval 81-100 (kategori tinggi),. 42 peserta didik mendapat nilai pada interval 61-80 (kategori sedang). Sebagian besar peserta didik yaitu 50 orang mendapat nilai pada interval 4-60 (kategori rendah). Sugiyono (2014, hlm. 409), mengemukakan, bahwa penelitian $\mathrm{R} \& \mathrm{D}$ terdiri dari 10 langkah berikut: (1) Potensi dan masalah, (2) Pengumpulan data, (3) Desain produk, (4) Validasi desain, (5) Revisi desain, (6) Uji coba produk, (7) Revisi produk, (8) Uji coba pemakaian, (9) Revisi produk, dan (10) Produksi masal.

Dalam penelitian ini, penulis melakukan pengembangan Buku Teks
Digital Interaktif melalui lima tahapan, yaitu: (1) Studi Pendahuluan (Pemahaman Konsep dan Penggunaan Sumber Belajar), (2) Studi Pustaka, (3) Pembuatan Draft dan Desain Buku Teks Digital Interaktif, (4) Uji Validasi dan Revisi, (5) Uji Empiris Buku Teks Digital Interaktif, sehingga mendapatkan (6) Hasil. Hal ini seperti dikemukakan Sukmadinata (2011, hlm. 187) bahwa peneliti dari program S2 atau penyusunan tesis, kegiatan penelitian dan pengembangan dapat dihentikan sampai draft final, tanpa pengujian akhir. Hasil setiap tahapan dalam pengembangan Buku Teks Digital Interaktif ini pada tabel 2.

Tabel 2. Hasil Identifikasi Tahap Studi Pendahuluan

\begin{tabular}{|c|c|c|}
\hline No & $\begin{array}{c}\text { Identifikasi } \\
\text { Sumber Belajar }\end{array}$ & Hasil Temuan Buku teks \\
\hline & $\begin{array}{l}\text { Pemahaman Konsep } \\
\text { Peserta Didik } \\
\text { Kelas XI SOSHUM } 1\end{array}$ & $\begin{array}{c}\text { Skor terendah terdapat pada interval (4-60) yang diperoleh } 16 \text { orang } \\
\text { peserta didik }(53,33 \%) \text { dan skor tertinggi terdapat pada interval }(80-100) \\
\text { diperoleh } 3 \text { orang peserta didik }(9,99 \%)\end{array}$ \\
\hline & Kelas XI SOSHUM 2 & $\begin{array}{c}\text { Skor terendah terdapat pada interval (4-60) diperoleh } 16 \text { orang peserta } \\
\text { didik }(44,44 \%) \text { dan skor tertinggi terdapat pada interval }(80-100) \text { diperoleh } \\
2 \text { orang peserta didik }(5,55 \%) \text {. Adapun sebagian besar peserta didik, yaitu } \\
18 \text { orang }(50 \%) \text { memperoleh skor pada interval }(61-80) \text {. }\end{array}$ \\
\hline & Kelas XI SOSHUM 3 & $\begin{array}{c}\text { Skor terendah terdapat pada interval (35-42) diperoleh } 3 \text { orang peserta } \\
\text { didik }(8,57 \%) \text { dan skor tertinggi terdapat pada interval }(75-82) \text { diperoleh } 4 \\
\text { orang peserta didik }(11,42 \%) \text {. Adapun sebagian besar peserta didik, yaitu } \\
10 \text { orang }(28,57 \%) \text { memperoleh skor pada interval }(51-58) \text {. }\end{array}$ \\
\hline
\end{tabular}

Berdasarkan hasil wawancara kepada guru mata pelajaran Geografi, diketahui bahwa guru seringkali hanya menggunakan buku teks sebagai sumber belajar. Hal ini berdampak terhadap pemahaman konsep peserta didik, karena sub pokok bahasan yang dijelaskan oleh guru terkesan menjadi kurang jelas sehingga peserta didik cenderung malas untuk mendengarkan dan belajar di kelas. Tahap studi pendahuluan juga menghasilkan data bahwa pemahaman konsep sebagian besar peserta didik ada pada kategori rendah.

Adapun hasil studi pustaka yaitu: 1) Dari berbagai penelitian terkait menunjukkan bahwa Buku Digital memberikan hasil belajar yang lebih baik dibandingkan dengan yang tidak menggunakannya, serta mampu meningkatkan pemahaman konsep peserta didik. 2) Terdapat beberapa software yang dapat digunakan untuk membuat Buku Teks Digital Interaktif, di antaranya yaitu: Boxoft Flipbook Writer, Digital Magazine Creator, 3D Pageflip Professional, Kvisoft Flipbook Maker Pro, dan Sigil. 3) Hasil studi pustaka mengenai teori pemahaman konsep sebagai berikut, (a) pemahaman konsep adalah kemampuan menangkap pengertian-pengertian seperti mampu mengungkap suatu materi yang disajikan kedalam bentuk yang lebih dipahami, mampu memberikan interpretasi dan mampu mengaplikasikannya, (b) pemahaman konsep meliputi tiga tipe kemampuan yaitu translasi (menerjemahkan), interpretasi, dan ekstrapolasi.

Tahap ketiga yaitu pembuatan draft dan desain, merupakan tahap penting dalam pengembangan Buku Teks Digital Interaktif. Tahap pembuatan draft dan 
desain terdiri dari desain konten materi, Hasil tahapan ini dapat dilihat pada Tabel 3 konten media, dan desain pembelajaran. berikut ini.

Tabel 3. Hasil Identifikasi Tahap Pembuatan

Draft dan Desain Buku Teks Digital Interaktif

\begin{tabular}{|c|c|c|}
\hline No. & Jenis Desain & Hasil \\
\hline 1. & Desain Konten Materi & $\begin{array}{l}\text { a) Membuat peta konsep materi Lingkungan Hidup sesuai dengan } \\
\text { silabus Geografi SMA, } \\
\text { b) membuat garis besar isi materi sesuai dengan Kompetensi Inti, } \\
\text { Kompetensi Dasar, dan Tujuan Pembelajaran, } \\
\text { c) membuat jabaran materi, } \\
\text { d) menyusun draft pada Microsoft Word, kemudian di save dalam bentuk } \\
\text { file PDF agar dapat digunakan pada software 3D Flipbook Professional. }\end{array}$ \\
\hline 2. & Desain Konten Media & $\begin{array}{l}\text { a) Membuat animasi dalam bentuk flash, } \\
\text { b) mengedit konten video dan gambar agar sesuai dengan materi } \\
\text { pembelajaran, } \\
\text { c) memasukkan konten ke dalam Buku Teks Digital Interaktif melalui } \\
\text { software 3D Flipbook Professional. }\end{array}$ \\
\hline 3. & Desain Pembelajaran & $\begin{array}{l}\text { a) Membuat RPP penggunaan Buku Teks Digital Interaktif dalam } \\
\text { pembelajaran yang disesuaikan dengan silabus (terlampir), } \\
\text { b) membuat instrumen penilaian berupa validasi materi dan media } \\
\text { beserta rubrik penskoran, dan soal tes pemahaman konsep. }\end{array}$ \\
\hline
\end{tabular}

Tahap keempat adalah validasi draft Buku Digital Teks Interaktif, yang dilakukan oleh dua validator materi dan satu validator media.

Validator materi I adalah Prof. Dr. Wanjat Kastolani, M.Pd. Beliau memiliki keahlian di Bidang Ilmu Geografi Lingkungan. Hal ini sesuai dengan materi yang terdapat dalam Buku Teks Digital Interaktif, yaitu Lingkungan Hidup.

Pada awalnya, validator materi memberikan skor total 18 dengan persentase $45 \%$ (kategori kurang layak). Setelah dilakukan perbaikan, validator materi memberikan skor total 35 dengan persentase 87,5\% (kategori sangat layak).

Validator materi II adalah Dr. Lili Somantri, S.Pd, M.Si. Beliau aktif sebagai penulis buku mata pelajaran Geografi untuk kelas X, XI, dan XII SMA. Hal ini sesuai dengan Buku Teks Digital Interaktif yang penulis kembangkan, yaitu mata pelajaran Geografi untuk kelas XI, materi Lingkungan Hidup.

Pada Buku Teks Digital Interaktif I, validator materi memberikan skor total 39 dengan persentase 97,5\% (kriteria sangat layak). Sedangkan pada Buku Teks Digital Interaktif II memberikan skor total 37 dengan persentase 92,5\% (kriteria sangat layak).

Validator media adalah Dr. Ahmad Yani, M.Si. Beliau merupakan seorang dosen pengajar di Departemen Geografi UPI. Adapun salah satu mata kuliah yang diampu oleh beliau adalah Media Pembelajaran Geografi. Hal ini sesuai dengan tujuan validasi media, yaitu untuk menyesuaikan media dalam Buku Teks Digital Interaktif dengan salah satu materi dalam pelajaran Geografi, yaitu Lingkungan Hidup.

Pada Buku Teks Digital Interaktif I validator media memberikan skor total 33 dengan persentase $82,5 \%$ (kriteria sangat layak), sedangkan pada Buku Teks Digital Interaktif II memberikan skor total 34 dengan persentase $85 \%$ (kriteria sangat layak).

Tahap ke-lima adalah uji empiris Buku Teks Digital Interaktif. Penggunaan Buku Teks Digital Interaktif I menunjukkan bahwa nilai pretest pada skor 28-36 merupakan interval dengan jumlah peserta didik terbanyak yaitu peserta didik 7 orang dengan persentase 26,92\%. Setelah dihitung, rata-rata skor untuk pretest kelompok eksperimen adalah 31,92. 
Setelah kegiatan pembelajaran, diketahui posttest terendah yang diperoleh peserta didik terdapat pada interval 40-48 yang diperoleh 2 orang peserta didik $(7,69 \%)$ dan skor tertinggi terdapat pada interval 85-93 diperoleh 6 orang peserta didik $(23,08 \%)$. Adapun sebagian besar peserta didik memperoleh skor interval 67-75, 76-84, dan 85-93 (23,08\%).

Data gain terendah yang diperoleh peserta didik pada pembelajaran ini terdapat pada interval 10-18 yang diperoleh 1 orang peserta didik $(3,84 \%)$ dan gain tertinggi terdapat pada interval 55-63 diperoleh 4 orang peserta didik $(15,38 \%)$, sebagian besar peserta didik memperoleh skor pada interval $46-54$ sebanyak 8 orang peserta didik $(30,77 \%)$.

Data hasil pemahaman konsep diperoleh dari hasil posttest dan tugas peserta didik. Hasil pemahaman konsep terendah yang diperoleh peserta didik pada pembelajaran ini terdapat pada interval $(51,5-58,5)$ yang diperoleh 1 orang peserta didik $(3,85 \%)$ dan pemahaman konsep tertinggi terdapat pada interval $(91,5-98,5)$ diperoleh 2 orang peserta didik $(7,69 \%)$, sebagian besar peserta didik memperoleh skor pada interval 75-5,82,5 yaitu 8 peserta didik $(30,77 \%)$.

Berdasarkan data, diketahui bahwa sebelum melaksanakan pembelajaran dengan menggunakan Buku Teks Digital Interaktif, pemahaman konsep peserta didik kelompok eksperimen berada pada rata-rata skor 31,92. Namun setelah melaksanakan pembelajaran dengan menggunakan Buku Teks Digital Interaktif, terjadi peningkatan rata-rata skor dari 31,92 menjadi 77,21. Dengan demikian, dapat disimpulkan bahwa Buku Teks Digital Interaktif I mampu meningkatkan pemahaman konsep peserta didik.

Pada penggunaan Buku Teks Digital Interaktif II, skor pretest terendah yang diperoleh peserta didik pada pembelajaran ini terdapat pada interval 10-18 yang diperoleh 4 peserta didik $(15,38 \%)$ dan skor tertinggi terdapat pada interval 55-63 diperoleh 2 peserta didik (7,69\%), sebagian besar peserta didik memperoleh skor pada interval 19-27 dan 28-36 yaitu sebanyak 6 peserta didik $(23,08 \%)$. Dari data pretest tersebut kemampuan awal peserta didik kurang maksimum.

Setelah kegiatan pembelajaran, skor posttest terendah yang diperoleh peserta didik pada pembelajaran ini terdapat pada interval 40-48 yang diperoleh 2 orang peserta didik $(7,69 \%)$ dan skor tertinggi terdapat pada interval 85-93 diperoleh 6 orang peserta didik $(23,08 \%)$, sebagian besar peserta didik memperoleh skor pada interval 67-75 dan 85-93 yaitu masingmasing 6 orang peserta didik $(23,08 \%)$.

Data gain terendah yang diperoleh peserta didik pada pembelajaran ini terdapat pada interval 10-18 yang diperoleh 2 peserta didik $(7,69 \%)$ dan skor tertinggi terdapat pada interval 55-63 diperoleh 5 peserta didik $(19,23 \%)$, sebagian besar peserta didik memperoleh skor pada interval 37-45 dan 46-54, masing-masing sebanyak 7 peserta didik (26,92\%). Dari data gain tersebut kemampuan peserta didik mengalami peningkatan pemahaman konsep yang cukup tinggi.

Data hasil pemahaman konsep diperoleh dari hasil posttest dan tugas peserta didik. data hasil pemahaman konsep terendah yang diperoleh peserta didik pada pembelajaran ini terdapat pada interval 51,5-58,5 yang diperoleh 1 orang peserta didik $(3,85 \%)$ dan pemahaman konsep tertinggi terdapat pada interval 91,5-98,5 diperoleh 4 orang peserta didik $(15,38 \%)$, sebagian besar peserta didik memperoleh skor pada interval 75,5-82,5 sebanyak 11 peserta didik (42,30\%).

Berdasarkan data, diketahui bahwa sebelum melaksanakan pembelajaran dengan menggunakan Buku Teks Digital Interaktif, pemahaman konsep peserta didik kelompok eksperimen berada pada rata-rata skor 31,15. Namun setelah melaksanakan pembelajaran dengan menggunakan Buku Teks Digital Interaktif, terjadi peningkatan rata-rata skor dari 31,15 
menjadi 79,62. Dengan demikian, dapat disimpulkan bahwa Buku Teks Digital Interaktif II mampu meningkatkan pemahaman konsep peserta didik.

Namun demikian, terdapat perbedaan pada hasil pada setiap komponen pemahaman konsep. pada penggunaan Buku Teks Digital Interaktif I, komponen translasi memiliki nilai rata-rata 5, interpretasi memiliki dengan nilai rata-rata 3, dan ekstrapolasi memiliki nilai rata-rata 2. Sedangkan pada penggunaan Buku Teks Digital Interaktif II, komponen translasi memiliki nilai rata-rata 5, interpretasi memiliki dengan nilai rata-rata 3 , dan ekstrapolasi memiliki nilai rata-rata 4 . Dapat disimpulkan bahwa pada penggunaan Buku Teks Digital Interaktif I, komponen yang paling tinggi adalah translasi, dan paling rendah adalah ekstrapolasi. Sedangkan pada penggunaan Buku Teks Digital Interaktif II, komponen yang paling tinggi adalah translasi, dan paling rendah adalah interpretasi.

Pada bagian ini, akan dibahas mengenai hasil penelitian pengembangan Buku Teks Digital Interaktif melalui Research and Development (R\&D). Buku Teks Digital Interaktif yang dikembangkan diperuntukkan bagi pembelajaran Geografi kelas XI Sosial Humanira, pada materi Lingkungan Hidup.

Studi pendahuluan merupakan tahapan pertama yang dilaksanakan untuk mengetahui permasalahan yang ada di lapangan, dalam hal ini kelas XI SOSHUM di SMA Laboratorium Percontohan UPI Bandung. Tahap ini merupakan modifikasi dari tahapan pertama penelitian $R \& D$ menurut Sugiyono (2014), yaitu potensi dan masalah. Studi pendahuluan meliputi dua hal yaitu pemahaman konsep peserta didik dan sumber belajar yang digunakan dalam pembelajaran.

Hasil studi pendahuluan mengungkapkan bahwa hanya 9 dari 101 peserta didik dengan persentase $8,91 \%$ yang memiliki pemahaman konsep pada kategori tinggi. Berdasarkan data hasil uji empiris, dapat disimpulkan bahwa pemahaman konsep sebagian besar peserta didik kelas XI SOSHUM berada pada kategori rendah.

Hasil wawancara kepada guru mata pelajaran Geografi mengungkapkan bahwa guru seringkali hanya menggunakan Buku Teks sebagai sumber belajar. Berdasarkan hasil studi pendahuluan yang telah dikemukakan, maka diperlukan adanya berbagai upaya, salah satunya yaitu dengan pengembangan Buku Teks Digital Interaktif sebagai sumber belajar untuk pemahaman konsep peserta didik. Hal ini sesuai dengan pendapat Kemp (1994), yang menyatakan salah satu sumber belajar yang paling bermanfaat bagi pendidikan yaitu gambar diam yang diproyeksikan dapat berupa slide, film, program komputer, dan kombinasi media.

Tahapan kedua adalah studi pustaka mengenai pemahaman konsep dan Buku Teks Digital Interaktif. Tahap ini merupakan modifikasi dari tahapan kedua penelitian R\&D menurut Sugiyono (2014), yaitu pengumpulan data. Pemahaman konsep meliputi tiga dimensi yaitu (1) translasi, (2) interpretasi, dan ekstrapolasi. Translasi adalah kemampuan peserta didik untuk menerjemahkan sesuatu dari bentuk abstrak ke dalam bentuk konkret, dan menerjemahkan suatu simbol ke dalam bentuk lain, misalnya menerjemahkan bagan siklus. Adapun interpretasi adalah kemampuan peserta didik untuk membedakan antara kesimpulan yang diperlukan dengan yang tidak diperlukan, maupun memahami dan menafsirkan isi bacaan. Sedangkan ekstrapolasi adalah kemampuan peserta didik untuk menyimpulkan dan menyatakan lebih eksplisit, memprediksi konsekuensi akan tindakan yang digambarkan dari sebuah komunikasi, dan sensitif terhadap faktor yang mungkin membuat prediksi menjadi akurat.

Tahapan ketiga adalah pembuatan draft dan desain Buku Teks Digital Interaktif. Tahap ini merupakan modifikasi 
dari tahapan ketiga penelitian R\&D menurut Sugiyono (2014), yaitu desain produk. Pembuatan draft dan desain ini bertujuan untuk memudahkan proses pembuatan Buku Teks Digital Interaktif.

Tahap ini meliputi desain konten materi, konten media, dan desain pembelajaran. Adapun komponen yang terdapat dalam Buku Teks Digital Interaktif yaitu (1) halaman depan, (2) halaman hak cipta, (3) daftar isi, (4) KI (kompetensi inti), KD (kompetensi dasar), dan tujuan pembelajaran, (5) peta konsep, (6) teks, (7) animasi, (8) gambar, (9) video, (10) link ke situs Youtube, (11) tugas, (12) glosari, (13) cover belakang.

Desain konten materi diawali dengan membuat peta konsep materi Lingkungan Hidup sesuai dengan silabus Geografi SMA, membuat garis besar isi materi sesuai dengan Kompetensi Inti, Kompetensi Dasar, dan tujuan pembelajaran, kemudian membuat jabaran materi Lingkungan Hidup sesuai dengan peta konsep dan garis besar isi materi, menyusun draft pada Microsoft Word, kemudian disimpan dalam format PDF agar dapat diproses dengan menggunakan software 3D Pageflip Professional 1.6.8. Hal ini sesuai dengan keterangan perusahaan 3D Pageflip Software Co.,Ltd. (2008), yang terdapat pada situs 3dpageflip.com, bahwa 3D PageFlip Professional dapat membantu untuk mengkonversi file PDF ke buku digital 3D animasi dengan halaman flip, dan dapat menambahkan multimedia seperti musik dan video, bahkan link, gambar, YouTube, tombol yang fleksibel, dan lain-lain.

Adapun desain konten media di awali dengan membuat animasi dalam bentuk flash. Kemudian hal berikutnya yang dilakukan adalah mengedit konten video agar sesuai dengan materi pembelajaran. Selain video, terdapat pula konten gambar yang juga memerlukan proses editing.

Konten selanjutnya adalah menyusun desain pembelajaran yang terdiri atas membuat RPP penggunaan Buku Teks
Digital Interaktif dalam pembelajaran yang disesuaikan dengan silabus, serta membuat instrumen penilaian berupa validasi materi dan media beserta rubrik penskoran, dan soal tes pemahaman konsep.

Tahapan keempat adalah uji validasi dan revisi Buku Teks Digital Interaktif. Uji validasi dilakukan oleh tiga validator, terdiri dari dua validator materi dan satu validator media. Tahap ini merupakan modifikasi dari tahapan keempat dan kelima penelitian R\&D menurut Sugiyono (2014), yaitu validasi desain dan revisi desain. Adapun tujuan dari uji validasi ini adalah mengetahui kelayakan Buku Teks Digital Interaktif untuk digunakan sebagai sumber belajar, khususnya pada materi Lingkungan Hidup.

Validator materi pertama memiliki keahlian di bidang Ilmu Geografi Lingkungan. Hal ini sesuai dengan materi yang terdapat dalam Buku Teks Digital Interaktif, yaitu Lingkungan Hidup. Adapun validator materi kedua aktif sebagai penulis buku Geografi untuk kelas X, XI, dan XII SMA. Hal ini sesuai dengan Buku Teks Digital Interaktif yang dikembangkan, yaitu mata pelajaran Geografi untuk kelas XI, materi Lingkungan Hidup. Sedangkan validator media merupakan dosen dan salah satu mata kuliah yang diampu oleh beliau adalah Media Pembelajaran Geografi. Hal ini sesuai dengan tujuan validasi media yaitu untuk melengkapi dan menyesuaikan media dalam Buku Teks Digital Interaktif dengan materi Lingkungan Hidup.

Pada Buku Teks Digital Interaktif I, validator materi pertama memberikan saran perbaikan berupa menyesuaikan materi mengenai UU Lingkungan Hidup dengan UU terbaru, memberikan keterangan nama makhluk hidup pada animasi Aliran Energi, Rantai Pemangsa, dan Siklus Karbon, merevisi contoh komponen biotik dan abiotik dengan gambar kontekstual (yang terdapat di wilayah Bandung dan sekitarnya), merevisi gambar halaman depan (cover) dengan gambar kontekstual 
(yang terdapat di wilayah Bandung dan sekitarnya), serta menambahkan prolog dan kesimpulan.

Adapun validator materi kedua memberikan saran perbaikan berupa menyesuaikan susunan materi dengan tujuan pembelajaran, dan menambahkan contoh wilayah untuk mengkontekstualkan konsep. Sedangkan validator media memberikan saran perbaikan berupa konten buku harus sesuai dengan langkah kegiatan pembelajaran saintifik (Kurikulum 2013), dan tugas yang harus dikerjakan peserta didik harus spesifik, terukur, dan dapat dikerjakan peserta didik.

Pada Buku Teks Digital Interaktif II, validator materi pertama memberikan saran perbaikan berupa melengkapi materi lingkungan biofisik dan lingkungan sosial ekonomi dengan contoh nyata (yang terdapat di wilayah Bandung dan sekitarnya), merevisi istilah pohon berfungsi untuk "menyediakan" oksigen menjadi pohon berfungsi sebagai "penyedia" oksigen, merevisi gambar cover dengan gambar kontekstual (yang terdapat di wilayah Bandung dan sekitarnya), serta menambahkan prolog dan kesimpulan.

Adapun validator materi kedua memberikan saran perbaikan berupa penyesuaian susunan materi dengan tujuan pembelajaran, dan materi dikontekstualkan dengan pendekatan geografi. Sedangkan validator media memberikan saran perbaikan berupa konten buku harus sesuai dengan langkah kegiatan pembelajaran saintifik (Kurikulum 2013), dan perkaya dengan link internet atau online.

Berdasarkan saran yang dikemukakan oleh validator, dilakukan perbaikan pada Buku Teks Digital Interaktif. Setelah dilakukan perhitungan data hasil uji validasi, disimpulkan bahwa Buku Teks Digital Interaktif I dan II sangat layak untuk digunakan sebagai sumber belajar pada pembelajaran Geografi materi Lingkungan Hidup.

Tahapan kelima adalah uji empiris Buku Teks Digital Interaktif. Tahap ini merupakan modifikasi dari tahapan keenam penelitian $R \& D$ menurut Sugiyono (2014), yaitu uji coba produk. Tujuan dari uji empiris adalah untuk mengetahui keefektifan Buku Teks Digital Interaktif sebagai sumber belajar terhadap pemahaman konsep peserta didik. Uji empiris dilaksanakan di SMA Laboratorium Percontohan UPI Bandung, kelas XI SOSHUM 1, dengan jumlah sampel 26 peserta didik.

Penggunaan Buku Teks Digital Interaktif pada mata pelajaran Geografi dengan materi Lingkungan Hidup merupakan hal baru bagi peserta didik karena sebelumnya peserta didik kelas XI SOSHUM di SMA Laboratorium Percontohan UPI lebih banyak mendapatkan materi melalui metode ceramah, dengan menggunakan Buku Teks sebagai sumber belajar. Menurut SEAMOLEC dalam Draf Buku Siswa Simulasi Digital (2014), beberapa tujuan pengembangan buku digital di antaranya yaitu guru dapat memberikan catatan tertentu pada materi, mencari kata atau kalimat tertentu dalam materi, menampilkan file multimedia (audio dan video) yang dapat diputar untuk memperkaya konten buku. Hal tersebut sangat membantu siswa memahami materi ajar dengan lebih baik dan lebih cepat.

Buku Teks Digital Interaktif yang digunakan dikemas dalam bentuk flip book, dan bersifat interaktif, sehingga peserta didik dapat berinteraksi langsung dengan Buku Teks Digital Interaktif tersebut tanpa harus melibatkan orang lain dalam memahami konsep-konsep materi yang ada di dalamnya.

Pada penelitian ini, terdapat dua buku digital yang digunakan sebagai sumber belajar, yaitu Buku Teks Digital Interaktif I yang digunakan dalam pembelajaran pertama, dan Buku Teks Digital Interaktif II yang digunakan dalam pembelajaran kedua.

Berdasarkan hasil penelitian dan analisis data, dapat diketahui terdapat 
peningkatan pemahaman konsep peserta didik pada kelompok eksperimen yang menggunakan Buku Teks Digital Interaktif I dan II, serta kelompok kontrol yang menggunakan Buku Teks. Pada pembelajaran pertama, rata-rata skor pretest kelompok eksperimen sebesar 31,92 dan kelompok kontrol sebesar 33,46. Adapun pada pembelajaran kedua, rata-rata skor pretest kelompok eksperimen sebesar 31,15 dan kelompok kontrol sebesar 30,38. Dengan data tersebut dapat disimpulkan bahwa kemampuan awal peserta didik berada pada kategori rendah. Hal ini karena sebelum dilaksanakan kegiatan pembelajaran, sama sekali belum disampaikan materi mengenai Lingkungan Hidup kepada peserta didik.

Setelah dilakukan kegiatan pembelajaran yang berbeda, pada kelompok eksperimen menggunakan Buku Teks Digital Interaktif I dan II serta kelompok kontrol menggunakan Buku Teks, kemudian dilakukan posttest untuk mengetahui hasil pemahaman konsep peserta didik. Pada pembelajaran pertama, diperoleh ratarata skor posttest kelompok eksperimen sebesar 77,21 dan rata-rata skor posttest kelompok kontrol sebesar 65,76. Adapun rata-rata gain kelompok eskperimen sebesar 40 dan kelompok kontrol sebesar 32,37. Sedangkan pada pembelajaran kedua, diperoleh rata-rata skor posttest kelompok eksperimen sebesar 70,36 dan rata-rata skor posttest kelompok kontrol sebesar 65,76. Adapun rata-rata gain kelompok eskperimen sebesar 39,23 dan kelompok kontrol sebesar 35,38. Terjadi peningkatan pemahaman konsep terhadap dua kelompok tersebut karena keduanya mengalami perlakuan, berupa penyampaian materi Lingkungan Hidup. Namun demikian, dapat diketahui bahwa rata-rata skor posttest kelompok eksperimen yang menggunakan Buku Teks Digital Interaktif lebih tinggi dari pada kelompok kontrol yang menggunakan Buku Teks. Hal ini terjadi karena Buku Teks Digital Interaktif lebih efektif digunakan sebagai sumber belajar untuk pemahaman konsep dibandingkan dengan Buku Teks.

Berdasarkan hasil perhitungan statistika, diperoleh bahwa data hasil penelitian berdistribusi normal dan homogen, kemudian dilakukan uji hipotesis dengan menggunakan uji-t. Berdasarkan hasil uji-t diperoleh hasil bahwa nilai sig. (2-tailed) lebih kecil dari 0,05. Selain itu diketahui nilai tHitung pada kelompok eksperimen, kelompok kontrol, dan gain kedua kelompok lebih besar dibandingkan dengan nilai tTabel. Hal ini berarti $\mathrm{H}_{0}$ ditolak dan $\mathrm{H}_{1}$ diterima. Hal ini sesuai dengan pendapat Gunawan (2013) yang mengemukakan ketetapan terhadap diterimanya hipotesis ditunjukkan oleh nilai sig. (2-tailed). Dengan aturan keputusan, jika nilai sig. $>0,05$, maka $\mathrm{H}_{0}$ diterima, sebaliknya jika nilai sig. $<0,05$ maka $\mathrm{H}_{0}$ ditolak.

Dengan demikian, disimpulkan bahwa terdapat peningkatan pemahaman konsep antara hasil pretest dan posttest pada kelompok eksperimen maupun pada kelompok kontrol. Adanya peningkatan pemahaman konsep antara hasil posttest, gain, pada kelompok eksperimen dan kelompok kontrol dapat menunjukkan bahwa penggunaan Buku Teks Digital Interaktif I dan II maupun penggunaan Buku Teks dapat meningkatkan pemahaman konsep peserta didik.

Peserta didik kelompok eksperimen lebih termotivasi untuk mengikuti pembelajaran dibandingkan kelompok kontrol. Hal ini terbukti pada saat penyampaian hasil analisis video kasus, kelompok eksperimen sangat antusias mengikuti jalannya kegiatan pembelajaran sehingga terkesan hidup. Hal ini berbeda dengan kelompok kontrol yang pada saat kegiatan pembelajaran berjalan mereka tidak mengikuti dengan baik sehingga pembelajaran memberikan kesan membosankan. Sesuai dengan yang diungkapkan Ramdania dkk. (2007), bahwa siswa lebih tertarik terhadap flip book karena tampilannya yang lebih menarik dan interaktif daripada buku 
cetak. Hal ini juga dibuktikan dengan nilai posttest, dan nilai tugas yang lebih baik, yang menunjukan bahwa kelompok eksperimen memberikan banyak sikap yang positif seperti pada saat pembelajaran mereka sangat antusias mengikuti jalannya pembelajaran dibandingkan dengan kelompok kontrol.

Namun demikian, terdapat perbedaan tingkat efektifitas pada kedua buku digital tersebut. Berdasarkan hasil penelitian, diketahui bahwa Buku Teks Digital Interaktif II menghasilkan pemahaman konsep yang lebih tinggi dibanding dengan Buku Digital I. Terdapat beberapa alasan kecenderungan yang mengakibatkan hal tersebut, di antaranya yaitu Buku Teks Digital Interaktif I digunakan pada pertemuan pertama, dan peserta didik baru pertama kali menggunakannya. Oleh sebab itu, peserta didik masih belum terlalu paham bagaimana proses pembelajaran dengan menggunakan Buku Teks Digital Interaktif I. Hal ini berbeda dengan Buku Teks Digital Interaktif II, yang digunakan pada pertemuan kedua. Pada pertemuan kedua peserta didik sudah memahami tahapan proses pembelajaran dengan menggunakan Buku Teks Digital Interaktif II. Selain itu konsep yang terdapat pada Buku Teks Digital Interaktif I lebih banyak daripada Buku Teks Digital Interaktif II.

Berdasarkan alasan kecenderungan tersebut, dapat disimpulkan bahwa terdapat perbedaan hasil pemahaman konsep pada penggunaan Buku Teks Digital Interaktif I dan II. Hal ini karena Buku Teks Digital Interaktif I digunakan pada pertemuan pertama, dan memiliki konsep yang lebih banyak daripada buku kedua. Namun demikian, berdasarkan hasil penelitian, meskipun terdapat perbedaan hasil pemahaman konsep, baik penggunaan Buku Teks Digital Interaktif I maupun II sebagai sumber belajar mampu mengembangkan pemahaman konsep peserta didik. Sesuai dengan yang dikemukakan Mayer \& Moreno (2000) bahwa multimedia berbasis komputer yang menghadirkan gambar animasi dan kata-kata berupa narasi mempunyai interaktifitas dan efektivitas yang cukup tinggi untuk meningkatkan pemahaman siswa terhadap materi yang dipelajari. Dengan demikian, dapat disimpulkan bahwa penggunaan Buku Teks Digital Interaktif I dan II yang menghadirkan konten gambar, animasi, teks, dan video berpengaruh terhadap pemahaman konsep peserta didik.

\section{SIMPULAN}

Terdapat beberapa simpulan yang diperoleh, yaitu sebagai berikut. 1) Berdasarkan hasil tahapan studi pendahuluan, diketahui bahwa pemahaman konsep sebagian besar peserta didik kelas XI SOSHUM termasuk pada kategori rendah. Oleh karena itu, diperlukan adanya berbagai upaya, salah satunya dengan pengembangan Buku Teks Digital Interaktif untuk pemahaman konsep. 2) Pengembangan Buku Teks Digital Interaktif untuk pemahaman konsep peserta didik dilakukan melalui lima tahapan, yaitu (1) studi pendahuluan, (2) studi pustaka, (3) pembuatan draft dan desain buku teks digital interaktif, (4) uji validasi dan revisi buku teks digital interaktif, dan (5) uji empiris buku teks digital interaktif. Berdasarkan hasil uji validasi materi dan media, menunjukkan Buku Teks Digital Interaktif I dan II sangat layak digunakan sebagai sumber belajar untuk pemahaman konsep peserta didik. Hal ini dilihat dari skor total yang diperoleh kedua Buku Teks Digital Interaktif tersebut. 3) Berdasarkan hasil uji empiris, diketahui bahwa terdapat perbedaan hasil tes peserta didik sebelum dan sesudah kegiatan pembelajaran pada kelas eksperimen dengan menggunakan Buku Teks Digital Interaktif I dan II dalam mata pelajaran Geografi pada materi Lingkungan Hidup. Perbedaan tersebut ditunjukkan adanya peningkatan nilai skor rata-rata untuk tes sebelum dan sesudah pembelajaran. Kemudian diketahui juga bahwa terdapat perbedaan hasil tes peserta 
didik sebelum dan sesudah kegiatan pembelajaran pada kelompok kontrol yang menggunakan Buku Teks I dan II dalam mata pelajaran Geografi pada materi Lingkungan Hidup. Perbedaan tersebut ditunjukkan adanya peningkatan nilai skor rata-rata untuk tes sebelum dan sesudah pembelajaran. Selain itu, diketahui juga bahwa terdapat perbedaan hasil pemahaman konsep antara kelas eksperimen yang menggunakan Buku Teks Digital Interaktif I dan II dengan kelas kontrol yang menggunakan Buku Teks I dan II. Perbedaan tersebut ditunjukkan adanya peningkatan pemahaman konsep peserta didik antara kelas eksperimen dan kelas kontrol. 4) Pemahaman konsep secara umum sudah meningkat, namun masih terdapat perbedaan dari segi komponen yaitu translasi, interpretasi, dan ekstrapolasi. Pada penggunaan Buku Teks Digital Interaktif I, komponen yang paling tinggi adalah translasi dan paling rendah adalah ekstrapolasi. Adapun pada penggunaan Buku Digital II, komponen yang paling tinggi adalah translasi dan paling rendah adalah interpretasi.

Berdasarkan hasil analisis dan pembahasan yang telah disampaikan, peneliti memberikan saran-saran sebagai berikut. 1) Hasil penelitian menunjukkan bahwa baik Buku Teks Digital Interaktif I maupun II efektif digunakan sebagai sumber belajar untuk meningkatkan pemahaman konsep peserta didik. Namun demikian, terdapat perbedaan efektifitas pada kedua buku digital tersebut. Berdasarkan hasil penelitian, diketahui bahwa Buku Teks Digital Interaktif II menghasilkan pemahaman konsep yang lebih tinggi dibanding dengan Buku Digital I. Oleh karena itu, disarankan untuk dilakukan beberapa revisi pada Buku Teks Digital Interaktif I, salah satunya mengenai konten animasi, sebaiknya menggunakan gambar kontekstual dalam proses pembuatannya. 2) Penggunaan Buku Teks Digital Interaktif sebagai sumber belajar menunjukkan terdapat peningkatan pema- haman konsep peserta didik. Oleh karena itu, apabila memungkinkan disarankan Buku Teks Digital Interaktif dapat digunakan oleh guru untuk meningkatkan pemahaman konsep peserta didik pada materi lainnya. 3) Pada penggunaan Buku Teks Digital Interaktif I masih terdapat komponen pemahaman konsep yang rendah yaitu komponen ekstrapolasi dan pada penggunaan Buku Teks Digital Interaktif II yaitu komponen interpretasi. Oleh karena itu, disarankan untuk mengembangkan Buku Teks Digital Interaktif yang lebih menekankan pada komponen ekstrapolasi dan interpretasi, dengan memperbaiki atau menambahkan konten-konten seperti video dan animasi.

\section{DAFTAR PUSTAKA}

Andina, E. (2011). Buku Digital dan Pengaturannya. Jurnal Kepakaran Aspirasi, Vol. 2, No. 1, Juni 2011, 119-146.

Gunawan, A. M. (2013). Statistik untuk Penelitian Pendidikan. Yogyakarta: Parama Publishing

Kemp, J. (1994). Proses Perancangan Pengajaran (Edisi Terjemahan oleh Asril Marjohan I). Bandung: Penerbit ITB

Magasing, R. (2012). Pengaruh Pemanfaatan Hutan Mangrove Sebagai Sumber Pembelajaran Geografi Terhadap Hasil Belajar. Bandung: Tesis SPs UPI: Tidak diterbitkan

Mayer RE \& Moreno R. (2000). Aids to Computer-based Multimedia Learning. Learning and instruction 12 (2002):107-119. Perdana, B. (2013). Pengembangan Buku Digital Interaktif (BUDIN) Berbasis Adobe Creative Suite Pada Materi Genetika di $S M K$. Semarang. Skripsi Universitas Negeri Semarang: Tidak diterbitkan.

Ramdania, DR. Sutarno H \& Waslaluddin. (2007). Penggunaan Media Flash Flip Book Dalam Pembelajaran Teknologi Informasi dan Komunikasi Untuk Meningkatkan Hasil Belajar Siswa. Jurnal Pendidikan 1(1):1-6.

Rohani, A. (1997). Media Instruksional Edukatif. Jakarta: Rineka Cipta 
SEAMOLEC (The Southeast Asian Soetomo. (1993). Dasar-Dasar Interaksi Bahan Ministers of Education Organization Mengajar. Surabaya: Usaha Nasional.

Regional Open Learning Centre), Tim. Sugiyono. (2014). Metode Penelitian (2014). Draft Buku Siswa Simulasi Digital. Kuantitatif, Kualitatif dan Kombinasi (Mix [Online]. Tersedia: http:/ / www.scribd.com/doc/220204747 /5-Buku-Digital-7maret2014\#scribd. [21 Februari 2015] Method). Bandung: Alfabeta.

3D Pageflip Software Co.,Ltd. (2008). Software 3D Pageflip. [Online]. Tersedia: 3dpageflip.com. [4 Maret 2015. 